\title{
Homeland Security Data Mining Using Social Network Analysis
}

\author{
Hsinchun Chen \\ Director, Artificial Intelligence Lab \\ University of Arizona \\ NSF COPLINK and Dark Web projects
}

The tragic events of September 11th have caused drastic effects on many aspects of society. Academics in the fields of computational and information science have been called upon to help enhance the government's ability to fight terrorism and other crimes. Keeping in mind the special characteristics of crimes and securityrelated data, data mining techniques can contribute in six areas of research: information sharing and collaboration, security association mining, classification and clustering, intelligence text mining, spatial and temporal crime pattern mining, and criminal/terrorist network analysis. Grounded on social network analysis (SNA) research, criminal network analysis and terrorist network analysis have been shown to be most promising for public safety and homeland security. Based on the University of Arizona's highly successful COPLINK and Dark Web projects, we will discuss relevant SNA for "dark networks" (criminal and terrorist networks). Selected techniques, examples, and case studies will be presented based on gang/narcotic networks, US extremist networks, Al Qaeda member networks, and international Jihadist web site and forum networks. Unique homeland security challenges and future directions will also be presented. 